\title{
STRENGTHENING SME COMPETITIVENESS THROUGH FINANCIAL SUPPORT
}

\author{
HADZIC Miroljub ${ }^{1}$, PAUNOVIC Branka ${ }^{2}$ \\ ${ }^{1}$ Singidunum University, Belgrade ( SERBIA) \\ ${ }^{2}$ Novi Sad School of Business, Novi Sad (SERBIA) \\ E-mail:mhadzic@singidunum.ac.rs
}

\begin{abstract}
Serbian SMEs after 2000 experienced high growth rate and become an important economic subject. During the economic crisis SMEs faced with severe problems. With economic recovery from 2015 on SMEs again have positive business demography. If look in SME`s business performances one cannot be satisfied. SMEs have experienced low level of profitability and competitiveness. Low efficiency, namely low gross value added, GVA made no room for savings and investments into development. The share of gross savings and investments into gross domestic product, GDP has for long time been less than 1/5. Thanking to high and increasing foreign direct investments total investments are on the level that made room for increase in rate of growth. The average rate of growth, 2-3\% p.y. is insufficient to catch up other transitory economies. External sources of financing SMEs are limited and the discrepancy between demand for financial sources and supply is more than one billion euros. The difficult access to finance by SMEs can be explained by biased approach of banks toward large companies, problem of bank`s non - performing loans, high interest rates and high requirements of banks.
\end{abstract}

The paper examines low efficiency of SMEs, especially problem of access to finance and try to recommend measures to overcome them.

Keywords: transition, SME, entrepreneurship

JEL: L26

DOI: 10.5937/intrev2103163H

UDC: $336.563: 334.7$

339.13

COBISS.SR-ID 55164681 


\section{INTRODUCTION}

Last five years Serbian economy recovered after six years of stagnation. The most severe economic problems, the budget deficit and foreign debt, were put under control, and macroeconomic stability was achieved. Transition process continued. Along with economic recovery SMEs have fast growth rate with a positive business demography.

In the period 2001-2008 investments volume grew, but during the crisis investments activities were mostly hampered, and are still below the level before the crisis. Total savings and investments are below 1/5 of the Gross Domestic Product, GDP. This is partially overcome by Foreign Direct Investments, FDI inflow between 2-3 billion euros p.y. Investments per company and per employee are also low and the structure of investments is not favourable. The efficiency of investments is low and SMEs are well behind large companies.

SMEs are facing with limits of growth, as follows: non finished market reforms, too high fiscal duties, difficult access to finance. Higher rate of economic growth asks for fastening SMEs growth and development.

\section{RECENT TRENDS IN SMES DEVELOPMENT AND THEIR COMPETITIVENESS}

Serbian SME became an important economic subject, due to the fast growth and development during the first phase of transition (GDP growth rate 2001-2008 was 5.4\%). It was due to fast growth, economic reforms, favourable business environment and supportive measures. SMEs form $99.9 \%$ out of total economic agents by number (360 thousand entities), engage $44 \%$ of total employees and created $1 / 3$ of total Gross Value Added, GVA and 28\% of total Gross Domestic product, GDP [1].

During the economic crisis the number of new established companies and shops declined, while the number of closed increased. Small and micro companies and shops were mostly hampered. A negative trend of decreasing total number of economic subjects occurred, with maximum in 2011. With economic recovery from 2015 the number of new established companies and shops became again higher than the number of closed, with a tendency of increasing the difference.

In spite of fast growth and development SME didn't improve their efficiency. The number of employees per company is still too small and also the number of fast development companies. During the crisis due to decreasing number of employees, the overall efficiency was improved. SME are oriented toward domestic market mainly.

Comparing figures in 2012 and 2016 the growth was the fastest among small and micro companies 1,5 p.p. p.y. The growth in GVA per employee is slow, as it increased $2.4 \%$ only and reached $13.856 €$ in non - financial sector, out of which $11.8856 €$ in SMEs. It says that efficiency is lower for $14 \%$ in comparison to the average, or 33\% in comparison to large companies [1] The low level of productivity firstly, cannot open enough room for investments and secondly, it points low level of the competitiveness.

The average employment per SME in Serbia is 2.5 while in EU is 4 . The productivity is lower 3.7 times than in EU, and it is higher in comparison to Bulgarian SMEs only [1].

World Bank Doing Business Report [2] ranked Serbia as the $48^{\text {th }}$. It is better placed than majority of neighbouring countries, except North Macedonia and Slovenia. The main reform steps were related to construction permit, the cadastre of immovable, while administration of foreign trade was at the same level [2].

Innovation Report labelled Serbia together with 17 countries as a "modest innovator" [3]. Serbia was ranked as the $55^{\text {th }}$. Its Innovation Index is 0.33 , while the EU average is 0.5 and it is better placed than Bosnia and Herzegovina and Albania, only [3]. 


\section{INVESTMENT ACTIVITY}

Investment activity until 2008 grew fast [4]. Investment activity, although increased during the economic recovery, is still under the level before the crisis. The share of aggregate saving and investments in GDP is under $20 \%$ only, and compensated by foreign direct investments, FDI in recent years [5]. The volume of investments per employee is low in comparison to other transitory economies. The structure of investments is not favourable and the efficiency of investments is not favourable [1].

There are several factors behind low investments activity: low level of the macroeconomic stability, the lack of supportive measures for increase in savings, poor structure of financial system and under developed financial market.

Low volume of investments is the most serious limit for growth and development, restructuring and strengthening competitiveness. The sole economic subjects who succeed to recover investments to the level before the crisis were large companies and sole entrepreneurs (Graph 1).

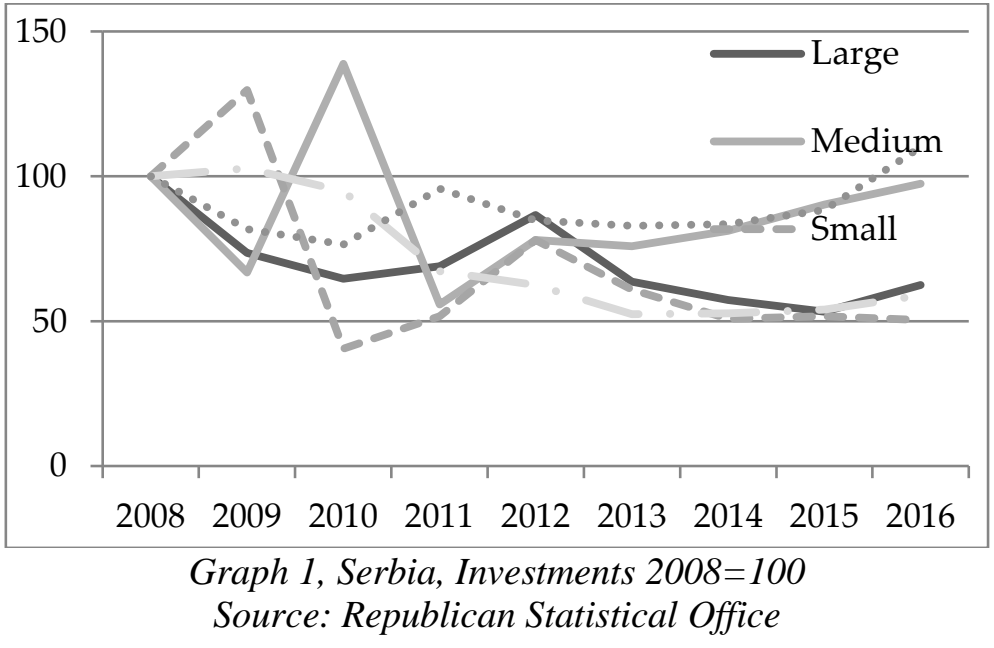

Investments per employees is increasing for large and medium scale companies and entrepreneurs, but not for small and micro companies (Graph 2).

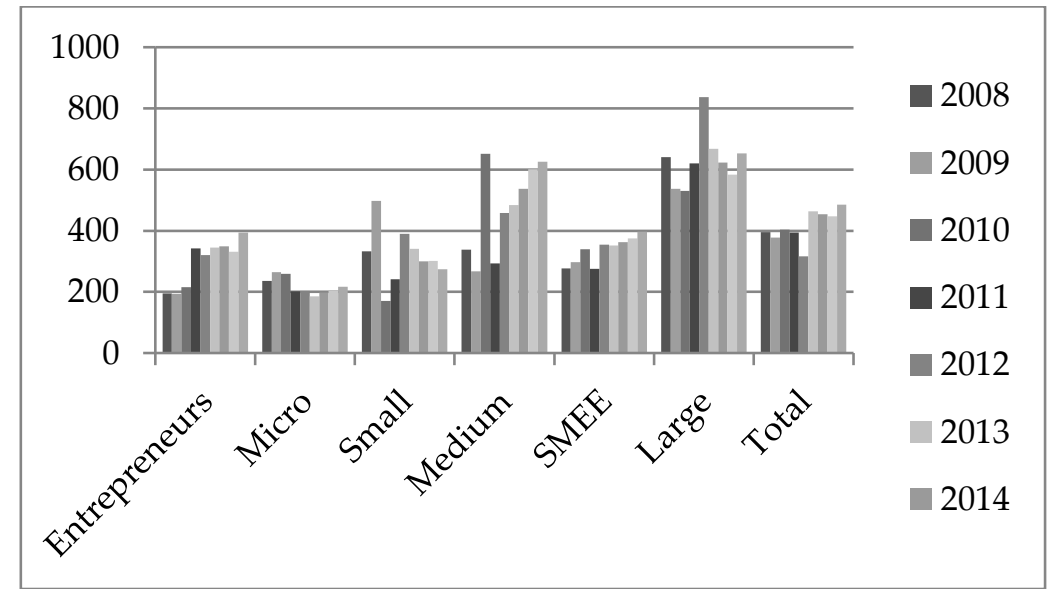

Graph 2, Serbia, Investments per employee (thousand RSD)

Source: Republican Statistical Office

Low share of investments in the gross value added, GVA (under 30\%), means that the productive capacity of domestic firms is modest to make room for development. In recent years the share of investments in GVA for large companies was stable around 30\% and for SMEs still under 30\%.

Low level of domestic savings is partially compensated with high volume of FDI, 2-3 billion $€$ per year. However firstly, the Government subsidies foreign investors and secondly, foreign investments policy is not adequate, as those investments are mainly based on the low technological level and oriented toward domestic market [6]. 
Large companies only had investments per company more than 4 million $€$, while SMEs 7.6 thousand $€$ per company (Table 1 ). Investments per employee are low. It is additionally proved by data related to the share of investments in turnover and the share of investments in GVA.

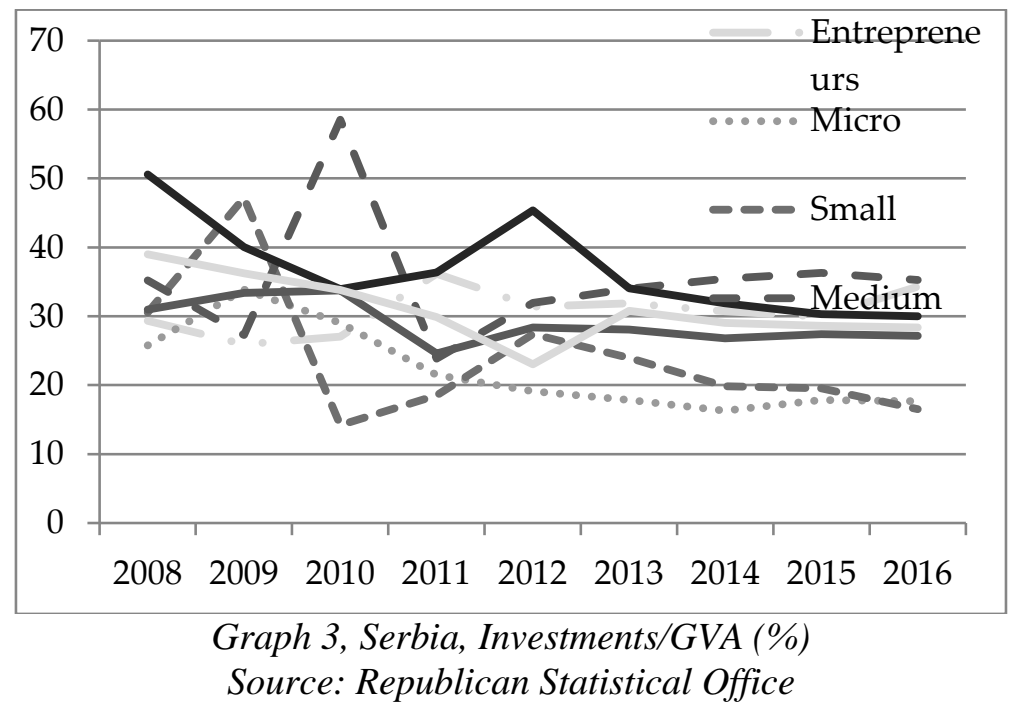

Table 1. Serbia, Investment Ratios ( $€$, \%)

\begin{tabular}{ccccccc}
\hline & Entrepre-neurs & Micro & Small & Medium & SME & Large \\
\hline Invest./company $€$ & 2.776 & 3.157 & 4.976 & 509.214 & 7.652 & 4.083 .404 \\
Inv./employee $€$ & 2.735 & 1.677 & 2.487 & 4.975 & 3.099 & 4.818 \\
Inv./turnover \% & 7,5 & 2,3 & 3,2 & 6,3 & 4,8 & 7,6 \\
Invest./ GVA \% & 29,9 & 17,9 & 19,5 & 36,3 & 27,4 & 30,3 \\
\hline
\end{tabular}

Source: Republican Statistical Office

The marginal capital coefficient was decreasing during last several years, which points that for each dinar of the increase in GVA is necessary to invest more and more.

Table 2. Serbia, The Structure of Investments (2016, million RSD)

\begin{tabular}{ccccc}
\hline & Total & Construction & Equipment & Rest \\
\hline Total & 617.966 & 245.640 & 314.042 & 58.284 \\
Entrepreneurs & 97.502 & 42.315 & 46.719 & 8.468 \\
Micro & 33.313 & 11.021 & 19.262 & 3.030 \\
Small & 55.929 & 18.391 & 32.181 & 5.357 \\
Medium & 145.179 & 74.362 & 62.240 & 8.577 \\
SME & 331.924 & 146.089 & 160.402 & 25.432 \\
Large & 286.043 & 99.550 & 153.640 & 32.853 \\
\hline
\end{tabular}

Source: Republican Statistical Office

The structure of investments is not favourable (Table 2). The share of investments into equipment in total investments was $48 \%$ and even $44 \%$ for investments into immovable. The worst structure was recognised for medium scale companies.

\section{SOURCES FOR FINANCING}

Entrepreneurs point the lack of financial sources available as the most important limit for their starts and business development [11]. Entrepreneurs are not welcomed in banks, because of serious drawbacks, like: low financial results, lack of knowledge for business plan creation and short period of operation [7]. So, entrepreneurs are oriented to their own, family source for financing. Serbian financial systems is of banco-centric character, where banks offer more than $90 \%$ of total financial services [12]. There are no developed micro financing institutions, business angels, etc. [8] 
For banks additional problem was high level of non-performing loans, NPLs more than $20 \%$ of total portfolio for years. Banking sector has experienced a credit boom before the crisis and after credit activity almost halted, as foreign sources almost disappeared [13] [9]. Demand for finances is still pretty higher than its supply, which is assessed to more than 1 billion $€$ (Table 4) [10].

Table 3. Serbia, Potential financial gap (million $€$ )

\begin{tabular}{cccc}
\hline & Potential demand & Supply assessed & Financial gap \\
\hline Short term & $429-474$ & $196-217$ & $233-257$ \\
Medium term & $1.293-1.904$ & $589-651$ & $705-779$ \\
Total & $1.722-1.904$ & $785-668$ & $938-1.036$ \\
\hline
\end{tabular}

Source: [10]

\section{STRENGTHENING INVESTMENT ACTIVITY OF SMES}

The economic recovery fostering SME-s dynamism and development. It is necessary to push up the rate of growth by supporting companies whose rate of growth and development is fast.

The main limits for investments growth $[14,15]$ can be overcome with adequate measures of macroeconomic and development policies. There are still not restructured banks. The strengthening concentration of the banking sector is also important, as well as, to disperse structure of financial system [14].

Supporting entrepreneurial initiative is possible by quantitative supportive measures, with an aim to reach the critical number of SMEs and by qualitative measures, by which SMES would become more profitable and more competitive [16].

Regarding savings and investments, the aim is to push up the share of investments into GDP to $1 / 4$, by measures: putting down tax and other related duties mainly on the production and savings and to strengthen domestic savings; halting FDI subsidization and canalling FDI to the production with higher technological level and better involvement of domestic suppliers [17].

It is very important to safe recently reached macroeconomic stability [18]. For better access of entrepreneurs to finances it would be useful to start with creation and development of non - banking financial institutions, like micro-credit institutions, strengthening insurances, leasing, private pension funds, private equity funds and financial market as well [19].

\section{CONCLUSIONS}

Serbian SMEs prior to the economic crisis became an important economic subject. During the crisis small and micro companies were mostly hampered. The investments activity went down. During last several years the economic recovery is secured and again the business demography is positive.

In spite of positive trends, one cannot be satisfied with low efficiency and competitiveness of SMEs. Investment activity is also low. It is necessary to secure faster growth and share of investments into GDP.

The analysis pointed that SMEs are inefficient because of: high tax duties, non - finished market reforms and difficult access to finances. SMEs ought to be transformed into more efficient and competitive, making room for higher volume of investments. Macroeconomic measures ought to support fast growing entities. It is also important to secure better access to finance for SMEs, by transformation of financial system into lees bank-centric one and by development of financial market. 


\section{REFERENCES}

[1] Report on SMEE Development, Ministry of Economy, the Government of Serbia, 2018

[2] World Bank, Doing Business Report 2019

[3] Cornell University, INSTEAD, World Intellectual Property Organization (WIPO), the Global Innovation Index 2018

[4] Hadžić M., Zeković S., Rethinking deindustrialization, and the reindustrialization policy in Serbia, SPATIUM, No 40, August 2019, p. 14-22,

[5] Ministry of Finance of Republic of Serbia, CURRENT Economic Trends, January 2020

[6] Boljanović S., Hadžić M., Impact of Foreign Direct Investments on Serbian Industry, Industrija No 3 12017

[7] Hadžić M., Pavlović P., Finances for SME - Development Hindrance, 14th International Conference on Management, Enterprise and Benchmarking, MEB 2016, Obuda University, Budapest, Hungary, April 2016,

[8] Guene C., the Analysis and Assessment of Needs for Micro Crediting in Serbia, ILO, 2008

[9] Filipović M., Hadžić M., The Banking Sector in Serbia: Impact of Late Transition and the Global Crisis, „Overcoming the Crisis, Economic and Financial Developments in Asia and Europe“, Štefan B., Brada J.C., Kuboniwa M., eds., University of Primorska Press, Koper, 2012

[10] EIB, EU, Ministry of Economy, The Government of Serbia Ex - ante study to assess the potential future of Financial Institutions to deploy IPA resources in support SMEs in Serbia, 2017

[11] National Agency for Regional Development, TNS Media Gallup - Conditions, needs and problems of small and medium-sized enterprises and entrepreneurship, Belgrade, 2014

[12] National Bank of Serbia, Annual Financial Stability Report, Belgrade, 2015

[13] Vienna Initiative, Credit Guarantee Schemes for SME lending in CE and SEE, 2014

[14] Paunović Branka „Privatization shareholding and the development of financial markets” Savremena administracija , Beograd 2007

[15] Hadžić M., Pavlović P. - How to support investments activity in Serbian SMEs, 16th International Conference on Management, Enterprise and Benchmarking, MEB 2018, Obuda University, Budapest, Hungary, April 2018, Book of Abstracts, p. 28, Conference Proceedings, Szikora P., ed., p.130-142, Obuda University, Keleti Faculty of Business and Management, Budapest 2018

[16] The Draft Strategy for Research and Innovation for Smart Specialization, (RIS3), Government of Serbia, 2016

[17] Labus M., (2020), Transition and Post-conflict Macroeconomic Policies in Serbia, ECONOMIC ANNALS, Volume LXV, No. 226 / July - September 2020, p. 73-102

[18] National Bank of Serbia, Report on Inflation, February 2021

[19] Hadžić M., Pavlović P., Rethinking Strategy for SMEE Support in the Light of the Entrepreneurial Ecosystem, Emerging Science Journal, Vol 3, No, 2019, p. 389-394, eds.: Carlo Santulli, Joseph Walsh, Omid A. Yamini,

\section{Article history:}

Received 27 September2021

Accepted 17 December 2021 